\title{
Myocardial uptake of radioactively labelled free fatty acids
}

\author{
G. Westera* AND F. C. Visser $†$ \\ * Department of Nuclear Medicine, University Hospital, Rämistrasse 100,8091 Zürich. Switzerland and \\ †Department of Cardiology, Free University Hospital, De Boelelaan 1117, 1007 MB Amsterdam, The \\ Netherlands
}

KEY WORDS: Myocardial uptake, free fatty acids.

Structural variations in the carbon chain of free fatty acids influence the uptake of free fatty acids in the myocardium. To enable the use of free fatty acids in nuclear cardiology, various methods of introducing gammaemitting isotopes have been evaluated.

The uptake of various free fatty acids is described and structure-activity relationships deduced.

\section{Introduction}

In the search for a tracer substance to monitor fatty acid metabolism in the heart by myocardial scintigraphy, several different free fatty acids ('unesterified fatty acid', FFAs) analogues have been described.

Three factors are of prime importance, when judging the value of any radiopharmaceutical:

(a) the uptake in the target organ (also in relation to the uptake in other tissues),

(b) the residence time/elimination rate of the compound in/from the target organ,

(c) the biochemical pathway by which the compound is metabolized in the body.

The last two aspects are dealt with by authors in other contributions to this supplement, and will only be mentioned here when it is pertinent to the 'uptake' process. Thus, only FFAs, which have been labelled with gamma-emitting radionuclides and for which pertinent uptake data are available will be discussed here.

\section{'Normal' FFAs labelled with Carbon-11}

${ }^{11} \mathrm{C}$-labelled fatty acids (which are chemically indistinguishable from naturally occurring FFAs) have been studied in nuclear cardiology mainly to demonstrate their use in positron-emission tomography. Attention has been focussed on the dynamic behaviour of these compounds (their clearance from the heart) and mostly only qualitative measures of their uptake have been obtained ${ }^{(1,2)}$.

Myocardial uptake has been measured as the extraction fraction in dogs and rabbits and as the percentage of the injected dose per gram of tissue $\left(\%\right.$ i.d. $\left.\mathrm{g}^{-1}\right)$ in rats and mice (Table $\left.1^{(3-9)}\right)$.

The amount of data given in Table 1 hardly allow any conclusions, although there is general agreement with conclusions from other studies which will be discussed below.

Because of the need for a cyclotron to produce ${ }^{11} \mathrm{C}$ (which has a 20-min half life) and for a positron camera to detect this nuclide, a search for FFAs labelled with other nuclides has been in progress from the start. Focus has been on radiohalogenated and particularly radioiodinated compounds.

\section{FFAs labelled along the carbon chain}

The first attempt to visualize the heart using radiolabelled FFAs was with oleic acid, iodinated over the double bond ${ }^{(10,11)}$. Thus a product is obtained labelled in the middle of the carbon chain and with the bulky iodine in this position, myocardial uptake was relatively low ${ }^{(3,12)}$. The introduction of the smaller fluorine-18 atom in the same position did not influence uptake (Table $2^{(13)}$ ). This indicates that for a substituent in the middle of the carbon chain its size determines the influence on myocardial uptake. 
Table I Myocardial uptake of FFAs labelled with ${ }^{11} \mathrm{C}$ or ${ }^{14} \mathrm{C}$

\begin{tabular}{|c|c|c|c|c|}
\hline FFA & Animal & Uptake & Time (min) & Ref. \\
\hline 1- ${ }^{11} \mathrm{C}$-stearic acid & $\operatorname{dog}$ & $70 \%$ & & 3 \\
\hline $1-{ }^{11} \mathrm{C}$-oleic acid & dog & $61 \%$ & . & 3 \\
\hline \multirow[t]{3}{*}{$1-{ }^{11} \mathrm{C}$-palmitic acid } & $\operatorname{dog}$ & $52 \%$ & & 4 \\
\hline & rabbit & $23 \%$ & & 5 \\
\hline & mouse & $43 \%$ i.d. $\mathrm{g}^{-1}$ & $<0.5$ & 6 \\
\hline $16-{ }^{14} \mathrm{C}$-palmitic acid & rat & $2.6 \%$ i.d. $\mathrm{g}^{-1}$ & 5 & 7 \\
\hline $1-{ }^{11} \mathrm{C}$-octanoic acid & rabbit & $56 \%$ & & 4 \\
\hline 1-11 C-propanoic acid & mouse & $12 \%$ i.d. $\mathrm{g}^{-1}$ & 10 & 8 \\
\hline $1-{ }^{14} \mathrm{C}$-acetic acid & $\operatorname{dog}$ & $60 \%$ & & 9 \\
\hline
\end{tabular}

The following apply in the tables in this paper.

$\% \quad$ extraction fraction.

$\%$ i.d. percentage of injected dose in total organ.

$\%$ i.d. $\mathrm{g}^{-1}$ percentage of injected dose per gram of organ.

$\% \mathrm{~kg} \mathrm{~d} . \mathrm{g}^{-1}$ percentage of injected dose per gram of organ divided by body weight in

Time $\quad \mathrm{kg}$. $\quad$ Time after injection of uptake given in min (unless otherwise stated). Where possible the maximum uptake with its time after injection will be given. Maximum uptake in mice and rats is in less than 0-5-10 min.

FFA Free (unesterified) fatty acid.

The introduction of tellurium as a link in the carbon chain can be compared to the presence of a double bond ${ }^{(14)}$.

The effect of a (non-radioactive) methyl substituent along the chain will be treated separately (Table 8).

\section{Labelling in the 2-position}

Another way to influence biological behaviour of FFAs is to introduce a substituent on the carbon atom neighbouring the acid function (that is next to the $\mathrm{COOH}$ - group: the 2- or alpha-position). Halogens have been introduced there, with considerable reduction of myocardial uptake (Table $3^{(6,15)}$ ). An electrophilic substituent in the 2-position makes the organic acid stronger (i.e. more apt to dissociate its $\mathrm{H}^{+}$) and thus more hydrophilic ('water loving'). Especially fluorine and (to a lesser extent) chlorine will exert their influence via such a mechanism. This effect becomes less pronounced for

Table 2 Uptake in the heart of FFAs labelled in the middle of the carbon chain (for abbreviations see Table 1)

\begin{tabular}{|c|c|c|c|c|}
\hline FFA & Animal & Uptake & Time (min) & Ref. \\
\hline $1{ }^{11} \mathrm{C}$-oleic acid & dog & $61 \%$ & & 3 \\
\hline $9,10-{ }^{131} \mathrm{I}$-hexadecanolc* acid & $\operatorname{dog}$ & $33 \%$ & & 3 \\
\hline $1{ }^{14} \mathrm{C}$-oleic acid & rat & $3.42 \%$ i.d. $\mathrm{g}^{-1}$ & 5 & 12 \\
\hline \multirow[t]{3}{*}{ '131' I-oleic acid' } & rat & $1.78 \%$ i.d. $\mathrm{g}^{-1}$ & 5 & 12 \\
\hline & $\operatorname{dog}(L V) \dagger$ & $0-035 \%$ id $g^{-1}$ & 5 & 12 \\
\hline & dog & $0-060 \%$ i.d. $\mathrm{g}^{-1}$ & 30 & 12 \\
\hline \multirow[t]{3}{*}{.131I-linoleic acid' } & rat & $1 \cdot 34 \%$ i.d. $\mathrm{g}^{-1}$ & 5 & 12 \\
\hline & $\operatorname{dog}(L V) \dagger$ & $0-034 \%$ id $\mathrm{g}^{-1}$ & 5 & 12 \\
\hline & $\operatorname{dog}$ & $0.026 \%$ i.d. $g^{-1}$ & 30 & 12 \\
\hline $1-^{11} \mathrm{C}$-palmitic acid & mouse & $43 \%$ i.d. $\mathrm{g}^{-1}$ & $<0-5$ & 6 \\
\hline $9,10^{18} \mathrm{~F}$-stearic acid & mouse & $43 \%$ i.d. $\mathrm{g}^{-1}$ & $0-5$ & 13 \\
\hline \multirow[t]{3}{*}{$9.123 \mathrm{~m}$ Te-tellura-heptadecanoic acid } & rat & $3 \cdot 7 \%$ i.d. $\mathrm{g}^{-1}$ & 30 & 14 \\
\hline & mouse & $30-5 \%$ i.d. $\mathrm{g}^{-1}$ & 5 & 14 \\
\hline & mouse & $25 \%$ i.d. $\mathrm{g}^{-1}$ & 60 & 14 \\
\hline
\end{tabular}

- Iodinated linoleic and linolenic acid gave results, indistinguishable from iodinated oleic acid ${ }^{(3)}$. $+\mathrm{LV}$ : the uptake in the left ventricle (LV) is given. Right ventricular uptake was comparable. Atrial uptake tended to be less. 
Table 3 Myocardial uptake of 2-substituted FFAs (for units see Table 1)

\begin{tabular}{|c|c|c|c|c|}
\hline FFA & Animal & Uptake & Time (min) & Ref \\
\hline $1{ }^{11} \mathrm{C}$-stearic acid & mouse & $43 \%$ i.d. $\mathrm{g}^{-1}$ & $<0.5$ & 6 \\
\hline $2{ }^{18} \mathrm{~F}$-stearic acid & mouse & $11 \%$ id. $g^{-1}$ & 0.5 & 6 \\
\hline $2-^{34 m}$ Cl-stearic acid & mouse & $23 \%$ i.d. $\mathrm{g}^{-1}$ & $1 \cdot 5$ & 6 \\
\hline $2{ }^{77} \mathrm{Br}$-stearic acid & mouse & $15 \%$ i.d. $\mathrm{g}^{-1}$ & $0-5$ & 6 \\
\hline $2-^{12} 3$ I-stearic acid & mouse & $14 \%$ i.d. $\mathrm{g}^{-1}$ & 1.5 & 6 \\
\hline 2- ${ }^{131}$ I-hexadecanoic acid & mouse & $20 \%$ i.d. $\mathrm{g}^{-1}$ & $<1$ & 15 \\
\hline
\end{tabular}

the larger halogens bromine and iodine, but then the steric effect becomes more important and the heart uptake of 2-iodo- and 2-bromo-FFAs was found to be rather low ${ }^{(6,15)}$.

\section{Labelling in the omega-position}

Because the uptake of the 'iodinated oleic acid' was less satisfactory, it was proposed ${ }^{(3)}$ to label FFAs at the end of the carbon chain, where it would affect the stereochemistry of the carbon chain to the least extent. And if the halogen-label was to be iodine, its size would match that of a methyl group and moreover little polarization of the terminal carbon-halogen bond ( $\mathrm{C}-\mathrm{X}$-bond) would occur with accompanying little effect on the lipofilicity. It was thus found (Table $4^{(6,15-22)}$ ) that omega-iodinated compounds are taken up by the myocardium to about the same extent as 'normal' FFAs.

If the label is the more polarizing halogen bromine or chlorine, omega-labelled FFAs are taken up less ${ }^{(6)}$; this effect has for $F$ been offset by its small size: the uptake of a fluoro-compound equals that of an unlabelled $\mathrm{FFA}^{(13)}$.
As a result of these findings, labelling of FFAs is now almost exclusively in the omega-position.

\section{The influence of unsaturation}

The presence of a double bond in the carbon chain does not seem notably to influence the uptake of an FFA in the heart (Table $5^{(3,15,19,23)}$ ) although the results of different groups are not very consistent. Thus our finding ${ }^{(19)}$ that there is a significantly different uptake between the 17- and 18-carbon analogues (16-I-hexadecenoic acid and 17-Iheptadecanoic acid) is the consequence of the number of $\mathrm{C}$-atoms rather than of the unsaturation in the 16-I-hexadecenoic acid.

Again (as with the saturated FFAs) bromoinstead of iodo-labelling reduces uptake considerably ${ }^{(15)}$.

Contrary to the effect of a double bond, a triple bond ${ }^{(15,17,22)}$ reduces myocardial uptake considerably. This is a consequence of the more stringent stereochemical requirements imposed on the carbon chain by a triple compared with a double bond. Also the electronic configuration around a

Table 4 Uptake in the heart of omega-halogenated straight chain saturated FFAs with 16-18 C-atoms (for units see Table I)

\begin{tabular}{|c|c|c|c|c|}
\hline FFA & Animal & Uptake & Time (min) & Ref. \\
\hline 1- ${ }^{11} \mathrm{C}$-palmitic acid & mouse & $43 \%$ i.d. $\mathrm{g}^{-1}$ & $<0.5$ & 6 \\
\hline $16^{-18} \mathrm{~F}$-hexadecanoic acid ${ }^{*}$ & mouse & $41 \%$ i.d. $\mathrm{g}^{-1}$ & $\quad 0.25$ & 13 \\
\hline $17-^{18} \mathrm{~F}$-heptadecanoic acid* & mouse & $46 \%$ i.d. $\mathrm{g}^{-1}$ & 10 & 13 \\
\hline $17-{ }^{34 m} \mathrm{Cl}$-heptadecanoic acid & mouse & $17 \%$ i.d. $\mathrm{g}^{-1}$ & $<0-5$ & 6 \\
\hline $17-{ }^{77} \mathrm{Br}$-heptadecanoic acid & mouse & $17 \%$ i.d. $\mathrm{g}^{-1}$ & $<0-5$ & 6 \\
\hline $16^{131}$ I-hexadecanoic acid & mouse & $56 \%$ i.d. $\mathrm{g}^{-1}$ & $0-25-0-5$ & 15 \\
\hline \multirow[t]{5}{*}{ 17- ${ }^{131}$ I-heptadecanoic acid } & mouse & $37 \%$ i.d. $\mathrm{g}^{-1}$ & 0.75 & 6 \\
\hline & mouse & $40 \%$ i.d. $\mathrm{g}^{-1}$ & $0-5$ & 16 \\
\hline & mouse & $48 \%$ i.d. $\mathrm{g}^{-1}$ & 0.5 & 17 \\
\hline & rat & $8 \%$ i.d. $\mathrm{g}^{-1}$ & $1 \cdot 5$ & 18 \\
\hline & $\operatorname{dog}$ & $4.2 \%$ i.d. & 5 & 19 \\
\hline \multirow[t]{3}{*}{$16^{-131}$ I-hexadecanoic acid } & rat & $0-39 \% \mathrm{~kg} \mathrm{~d} \cdot \mathrm{g}^{-1}$ & 5 & 20 \\
\hline & rat & $6.59 \%$ i.d. & 1 & 21 \\
\hline & $\operatorname{dog}$ & $0.57 \% \mathrm{~kg} \mathrm{~d} \cdot \mathrm{g}^{-1}$ & 5 & 22 \\
\hline
\end{tabular}


Table 5 Myocardial uptake of various unsaturated FFAs (for abbreviations see Table I)

\begin{tabular}{|c|c|c|c|c|}
\hline FFA & Animal & Uptake & Time (min) & Ref. \\
\hline 16- ${ }^{13}{ }^{1} \mathrm{I}$-hexadecanoic acid & mouse & $56 \%$ i.d. $\mathrm{g}^{-1}$ & $0-25-0-5$ & 15 \\
\hline $16^{-131}$ I-9-hexadecenoic acid E & mouse & $55 \%$ i.d. $\mathrm{g}^{-1}$ & $0.5-0.75$ & 15 \\
\hline T- Z & mouse & $51 \%$ i.d. $\mathrm{g}^{-1}$ & $0-5-0.75$ & 15 \\
\hline $16^{-82} \mathrm{Br}-9-$ hexadecenoic acid & mouse & $39 \%$ i.d. $\mathrm{g}^{-1}$ & $0-0.25$ & 15 \\
\hline \multirow[t]{3}{*}{$16-131$ I-9-hexadecenoic acid } & mouse & $27 \%$ i.d. $\mathrm{g}^{-1}$ & $0-5$ & 23 \\
\hline & $\operatorname{dog}$ & $77 \%$ & & 3 \\
\hline & dog & $2.4 \%$ i.d. & 5 & 19 \\
\hline $14-{ }^{131}$ I-7-tetradecynoic acid & mouse & $19 \%$ i.d. $\mathrm{g}^{-1}$ & 0.25 & 17 \\
\hline $15-{ }^{131}$ I-9-pentadecynoic acid & mouse & $30 \%$ i.d. $\mathrm{g}^{-1}$ & $0-0-25$ & 17 \\
\hline $16^{-13} 1$ 1-9-hexadecyno1c acid & mouse & $43 \%$ i.d. $g^{-1}$ & $0-0.25$ & 17 \\
\hline $18^{-131} \mathrm{I}-9$-octadecynoic acid & mouse & $32 \%$ i.d. $\mathbf{g}^{-1}$ & $0-0-25$ & 17 \\
\hline $20-131-12$-eicosynoic acid & mouse & $39 \%$ i.d. $\mathrm{g}^{-1}$ & $0-0.25$ & 17 \\
\hline $16^{-131}$ I-hexadecanoic acid & $\operatorname{dog}$ & $0-57 \% \mathrm{~kg} \mathrm{~d} . \mathrm{g}^{-1}$ & 5 & 22 \\
\hline 14-131-9-hexadecynoic acid & dog & $0-49 \% \mathrm{~kg}$ d. $\mathrm{g}^{-1}$ & 5 & 22 \\
\hline
\end{tabular}

triple bond is different, probably increasing the polarity of the molecule.

\section{The influence of chain length-odd/even effect?}

The fatty acids which are mostly used by the body have 16 or 18 carbon atoms. As can be seen (Table $6^{(17,20)}$ ) the myocardial uptake of these FFAs is also highest. Obviously the uptake mechanism, which governs the transport of FFAs from the blood into the cells has a preference for these long-chain FFAs.

The higher uptake of FFAs for longer chains can also be seen with the unsaturated compounds (Table $5^{(17)}$ ) although the interpretation here is obscured by the influence of the triple bond. And the same has been observed for FFAs where Te is one of

Table 6 Uptake of FFAs in the heart with varying length of the C-chain-omega labelled, except ${ }^{123 m}$ Te (for abbreviations see Table I)

\begin{tabular}{|c|c|c|c|c|}
\hline FFA & Animal & Uptake & Time (min) & Ref. \\
\hline 11-125I-undecanoic acid & rat & $0-35 \% \mathrm{~kg} \mathrm{~d} \cdot \mathrm{g}^{-1}$ & 5 & 20 \\
\hline 13-125I-tridecanoic acid & rat & $0-30 \%$ kg d. $\mathrm{g}^{-1}$ & 5 & 20 \\
\hline 16-129I-hexadecanoic acid & rat & $0.39 \% \mathrm{~kg} \mathrm{~d} . \mathrm{g}^{-1}$ & 5 & 20 \\
\hline $19-{ }^{125} I$-nonadecanoic acid & rat & $1-00 \% \mathrm{~kg} \mathrm{~d} \cdot \mathrm{g}^{-1}$ & 5 & 20 \\
\hline $22-129$ I-docosanoic acid & rat & $0.79 \% \mathrm{~kg} \mathrm{~d} . \mathrm{g}^{-1}$ & 5 & 20 \\
\hline $27-123 \mathrm{I}-\mathrm{heptacosanoic}$ acid & rat & $.0 .25 \% \mathrm{~kg} \mathrm{~d} . \mathrm{g}^{-1}$ & 5 & 20 \\
\hline 13-131I-tridecanoic acid & mouse & $41 \%$ i.d. $\mathrm{g}^{-1}$ & 0.75 & 17 \\
\hline 14-1'1-tetradecanoic acid & mouse & $42 \%$ i.d. $\mathrm{g}^{-1}$ & $0-75$ & 17 \\
\hline 15-131I-pentadecanoic acid & mouse & $47 \%$ i.d. $\mathrm{g}^{-1}$ & 0.50 & 17 \\
\hline $16^{131}$ I-hexadecanoic acid & mouse & $56 \%$ i.d. $\mathrm{g}^{-1}$ & $0-50$ & 17 \\
\hline 17-1311-heptadecanoic acid & mouse & $48 \%$ i.d. $\mathrm{g}^{-1}$ & $0-50$ & 17 \\
\hline 18-131 I-octadecanoic acid & mouse & $32 \%$ i.d. $\mathrm{g}^{-1}$ & $0.5-0.75$ & 17 \\
\hline $20-131$ I-eicosanoic acid & mouse & $36 \%$ i.d. $\mathrm{g}^{-1}$ & 0.50 & 17 \\
\hline 8-82 Br-octanoic acid & mouse & $20 \%$ i.d. $\mathrm{g}^{-1}$ & 0 & 17 \\
\hline $11-^{82} \mathrm{Br}$-undecanoic acid & mouse & $45 \%$ i.d. $\mathrm{g}^{-1}$ & 0 & 17 \\
\hline $12-{ }^{-2} \mathrm{Br}$-dodecanoic acid & mouse & $41 \%$ i.d. $\mathrm{g}^{-1}$ & $0-75$ & 17 \\
\hline 123mTe-9-telluraheptadecanoic acid & rat & $5.5 \%$ i.d. $\mathrm{g}^{-1}$ & 60 & 24 \\
\hline $123^{\circ} \mathrm{Te}-9-$ telluratridecanoic acid & rat & $1.6 \%$ i.d. $\mathrm{g}^{-1}$ & 5 & 24 \\
\hline $15-\left({ }^{13}\right.$ I-4-iodophenyl)pentadecanoic acid (I-PPA) $\dagger$ & mouse & $35 \%$ i.d. $\mathrm{g}^{-1}$ & $2 \cdot 5$ & 25 \\
\hline $5-\left({ }^{13} 1\right.$ I-4-iodophenyl) valeric acid $\ddagger$ & mouse & $15 \%$ i.d. $\mathrm{g}^{-1}$ & $2 \cdot 5$ & 25 \\
\hline
\end{tabular}

† "I-PPA: $15-(*$-4-iodophenyl)pentadecanoic acid with *I for radioiodine.

$\ddagger$ Valeric acid = pentanoic acid. 
the links in the carbon chain (Table $6^{(24)}$ ). Observations with omega-bromo-substituted FFAs and

tr omega-halophenyl-substituted compounds (Table $6^{(17,25)}$ ) also confirm this point.

In nature, practically all FFAs occur with an even number of $\mathrm{C}$-atoms. The beta-oxidation metabolism of FFAs breaks these compounds down by chopping - off two C-atoms (an acetyl-group) at a time ${ }^{(26)}$. If there is an odd number of $\mathrm{C}$-atoms the last unit will have three $\mathrm{C}$-atoms (propionyl group). In the catabolic behaviour a clear odd/even effect has been observed with ${ }^{18} \mathrm{~F}$ as the label ${ }^{(13)}$.

Although it is difficult to establish because of the large standard deviations in the results and because one can hardly compare the results of one group with those of another, one may tentatively read from the data presented that FFAs with an odd number of $\mathrm{C}$-atoms in the chain are taken up by the heart to a lesser extent than even numbered ones. It must be borne in mind that the omega-iodine label in the case of FFA uptake can be treated as a methyl group. Therefore an omega-iodinated FFA must, for the sake of this argument, be considered as having a $\mathrm{C}$-chain with one extra atom. The reasoning is further complicated by the fact, that the odd/even effect is necessarily accompanied by a change in the length of the $\mathrm{C}$-chain. We have shown an odd/even effect more clearly in the $\operatorname{dog}^{(19)}$.

\section{Omega-phenyl substituted FFAs}

Because myocardial elimination of FFAs is fairly fast (half life values in man $\sim 10-20 \mathrm{~min}$ ) resulting (with radiohalogenated FFAs) in high blood levels and thus in high background levels in scintigraphy, several structural alterations in the $\mathrm{C}$-chain have been made to prolong myocardial residence time and to reduce (blood) background levels.

One approach has been to introduce a phenyl group in the omega-position and then label this aromatic ring with the radiohalogen. The radiohalogen will go to the ortho- (or 2-) or para- (or 4-) position. It was immediately established (in the case of omega-phenyl-pentadecanoic acid), that ortho substitution led to less uptake than para substitution $(\text { Table } 7)^{(27)}$. The para compound was taken up by the heart to about the same extent. as 'normal' omega-iodinated FFAs (Table $7^{(27-33)}$ ) although once again results from different papers are impossible to compare.

The uptake of the bromo-substituted phenylpentadecanoic acid was the same as for the iodocompound (Table $7^{(27)}$ ) indicating that the halogen label did not influence the polarity of the C-chain to an appreciable extent.

On the contrary, when the phenyl group was coupled to the $\mathrm{C}$-chain via an electron-rich linkage

Table 7 Myocardial uptake of omega-phenyl-and omega-vinyl-FFAs (for abbreviations see Tables 1 and 6)

\begin{tabular}{|c|c|c|c|c|}
\hline FFA & Animal & Uptake & Time (min) & Ref. \\
\hline \multirow[t]{2}{*}{ 17-I-heptadecanoic acid } & mouse & $37 \%$ i.d. $\mathrm{g}^{-1}$ & 0.75 & 6 \\
\hline & $\operatorname{dog}$ & $4.2 \%$ i.d. & 5 & 19 \\
\hline \multirow[t]{9}{*}{ I-PPA } & dog & $4.5 \%$ i.d. & 5 & 19 \\
\hline & dog & $4.5-6-0 \%$ i.d. & & 32 \\
\hline & mouse & $32 \%$ i.d. $\mathrm{g}^{-1}$ & 3 & 27 \\
\hline & mouse & $28-35 \%$ i.d. $\mathrm{g}^{-1}$ & $20-28$ & 28 \\
\hline & rabbit & $0-32 \%$ i.d. $\mathrm{g}^{-1}$ & 9 & 28 \\
\hline & rabbit & $0-82 \% \mathrm{~kg} \mathrm{~d} \cdot \mathrm{g}^{-1}$ & 9 & 28 \\
\hline & rat & $4.5 \%$ i.d. $\mathrm{g}^{-1}$ & 1 & 29 \\
\hline & rat & $17 \%$ i.d. $\mathrm{g}^{-1}$ & 1.5 & 30 \\
\hline & rat & $30 \%$ i.d. $\mathrm{g}^{-1}$ & 5 & 31 \\
\hline $15-f^{125}$ I-2-iodophenyl)pentadecanoic acid & mouse & $18 \%$ i.d. $\mathrm{g}^{-1}$ & 3 & 27 \\
\hline $14-\left({ }^{125}\right.$ I-4-iodophenyl)tetradecanoic acid & rat & $2.7 \%$ i.d. $\mathrm{g}^{-1}$ & 5 & 31 \\
\hline \multirow[t]{2}{*}{ Br-PPAt } & mouse & $30 \%$ i.d. $\mathrm{g}^{-1}$ & 3 & 27 \\
\hline & mouse & $33 \%$ i.d. $\mathrm{g}^{-1}$ & $0-5$ & 33 \\
\hline $15--^{82} \mathrm{Br}-2-$ bromophenyl)pentadecanoic acid & mouse & $22 \%$ i.d. $\mathrm{g}^{-1}$ & 3 & 27 \\
\hline${ }^{13}$ I-12-N(4-iodophenylsulphonamide)dodecanoic acid & mouse & $0.27 \%$ i.d. $\mathrm{g}^{-1}$ & 5 & 34 \\
\hline${ }^{131} \mathrm{I}-11$-N(4-iodophenylsulphonamide) undecanoic acid & mouse & $0.47 \%$ i.d. $\mathrm{g}^{-1}$ & 5 & 34 \\
\hline "I-E-18-iodo-17-octadecenoic acid & rat & $3.17 \%$ i.d. $\mathrm{g}^{-1}$ & 5 & 35 \\
\hline
\end{tabular}

† *Br-PPA: 15-(*Br-4-bromophenyl)pentadecanoic acid with * $\mathrm{Br}$ for radiobromine. 
such as in p-iodophenyl-sulphonamide alkanoic acids (Table $7^{(34)}$ ) no myocardial uptake was observed.

\section{Omega-vinyl substituted FFAs}

Another structural feature which (from the chemical point of view) belongs under the same heading (in stabilizing the iodine on the C-chain) as an omega-vinyl group, would be the omega-vinyl group, labelled with iodine trans with respect to the rest of the $\mathrm{C}$-chain. This leads to uptake in the heart comparable to that of omega-phenyl substitution (Table $7^{(35)}$ ).

\section{Methyl-branching of the carbon-chain}

Another structural feature for prolonging myocardial residence time of FFAs could be the introduction of a methyl group in the carbon chain, because this would block beta oxidation.

This seems to work reasonably well for ${ }^{14} \mathrm{C}$ and ${ }^{11} \mathrm{C}$ labelled FFAs (Table $8^{(7,36)}$ ), but far less so for omega-iodinated beta-methyl compounds ${ }^{(37)}$. In the former case uptake remains normal, whereas in the latter case the 5 -min retention period is considerably less than for the corresponding straight chain compounds.

The combination of para-phenyl substitution and a beta methyl group also does not work particularly well: again heart uptake is relatively low (Table $8^{(37)}$ ). However, here the relative shortness of the $\mathrm{C}$-chain may play an important role, because the corresponding longer chain para-iodophenyl- 3-methyl pentadecanoic acid shows relatively high uptake (Table $8^{(31)}$ ).

\section{Tellura fatty acids}

Apart from the former mentioned changes in FFA-structure, in which the C-chain remained essentially intact, another approach for prolonging myocardial half lives of FFAs has been to insert a tellurium atom ( $\mathrm{Te}$ ) as a link in the $\mathrm{C}$-chain. This also blocks the normal beta-oxidation mechanism (Table $9^{(14.24 .38-42)}$ ). For high uptake values the usual $\mathrm{C}$-chain length of 16 or 18 carbons was optimal.

Obviously the position of the $\mathrm{Te}$ in the C-chain is also of great influence on heart uptake: high uptake is only found if the $\mathrm{Te}$ is in the middle of the chain; positions too close to either end give essentially lower uptake.

Because of the unfavourable radiation characteristics of ${ }^{123 m} \mathrm{Te}$ (physical half life 120 days), the tellurium concept has been extended in that inactive Te is being inserted in the chain, whereas the chain is omega-labelled with radioiodine.

If the iodine is simply coupled to the carbon chain the iodine seems to be cut off directly ${ }^{(40)}$ and thus the tellurium-radioiodine concept was extended once more to include stabilization of the radioiodine as the para iodophenyl-(41) or the trans iodovinyl-(38.42) group. This was shown to work reasonably well.

Again it turned out that the Te must be in the middle of the $\mathrm{C}$-chain to get the higher uptake

Table 8 Uplake in the heart of methy/-substituted FFAs (for abbreviations see Tables I and 6)

\begin{tabular}{|c|c|c|c|c|}
\hline FFA & Animal & Uptake & Time (min) & Ref. \\
\hline $16^{-14} \mathrm{C}$-palmitic acid & rat & $2 \cdot 6 \%$ i.d. $\mathrm{g}^{-1}$ & 5 & 7 \\
\hline $1{ }^{14} \mathrm{C}-3$-methylheptadecanoic acid & rat & $4 \cdot 3 \%$ i.d. $\mathrm{g}^{-1}$ & 15 & 7 \\
\hline \multirow[t]{3}{*}{$1-{ }^{11} \mathrm{C}-3$-methylheptadecanoic acid } & rat & $2.9 \%$ i.d. $\mathrm{g}^{-1}$ & 30 & 36 \\
\hline & rat & $20 \%$ i.d. & & 36 \\
\hline & dog & $8.3 \%$ i.d. & 30 & 36 \\
\hline 16-123I-hexadecanoic acid & rat & $0-39 \% \mathrm{~kg} \mathrm{~d} \cdot \mathrm{g}^{-1}$ & 5 & 37 \\
\hline 13-125I-3-methyltridecanoic acid & rat & $0.13 \% \mathrm{~kg} \mathrm{~d} \cdot \mathrm{g}^{-1}$ & 5 & 37 \\
\hline $16^{-125} \mathrm{I}-3$-methylhexadecanoic acid & rat & $0.34 \% \mathrm{~kg} \mathrm{~d} \cdot \mathrm{g}^{-1}$ & 5 & 37 \\
\hline $14^{125} \mathrm{I}-3,3^{\prime}$-dimethyltetradecanoic acid & rat & $0-03 \% \mathrm{~kg} \mathrm{~d} \cdot \mathrm{g}^{-1}$ & 5 & 37 \\
\hline${ }^{125}$ I-PPA & rat & $0-69 \% \mathrm{~kg} \mathrm{~d} . \mathrm{g}^{-1}$ & 5 & 37 \\
\hline $8\left(^{125}\right.$ I-4-iodophenyl)-3-methyloctanoic acid & rat & $0.17 \% \mathrm{~kg} \mathrm{~d}^{-1}$ & 5 & 37 \\
\hline${ }^{125} \mathrm{I}-\mathrm{PPA}$ & rat & $2.98 \%$ i.d. $\mathrm{g}^{-1}$ & 5 & 31 \\
\hline 15-( ${ }^{125}$ I-4-iodophenyl)-3-methylpentadecanoic acid & rat & $4.62 \%$ i.d. $\mathrm{g}^{-1}$ & 5 & 31 \\
\hline $14-\left({ }^{125}\right.$ I-4-iodophenyl)tetradecanoic acid & rat & $272 \%$ i.d. $\mathrm{g}^{-1}$ & 5 & 31 \\
\hline $14-\left({ }^{129}\right.$ I-4-iodophenyl)-3-methyltetradecanoic acid & rat & $1.71 \%$ i.d. $\mathrm{g}^{-1}$ & 5 & 31 \\
\hline
\end{tabular}


Table 9 Myocardial uptake of FFAs with tellurium as a link in the carbon chain, including omega-phenyl and omega-vinyl compounds (for abbreviations see Table I)

\begin{tabular}{|c|c|c|c|c|}
\hline FFA & Animal & Uptake & Time (min) & Ref \\
\hline 13-123mTe-telluraheptadecanoic acid & rat & $1 \cdot 1 \%$ i.d. $\mathrm{g}^{-1}$ & 5 & 38 \\
\hline \multirow[t]{4}{*}{ 9-123m Te-telluraheptadecanoic acid } & rat & $3.7 \%$ i.d. $\mathbf{g}^{-1}$ & 30 & 14 \\
\hline & mouse & $30-5 \%$ i.d. $\mathrm{g}^{-1}$ & 5 & 14 \\
\hline & rat & $3.3 \%$ i.d. $\mathrm{g}^{-1}$ & 30 & 24 \\
\hline & rat & $5.5 \%$ 1.d. $\mathrm{g}^{-1}$ & 60 & 24 \\
\hline $11.123 \mathrm{~m} T e$-telluraheptadecanoic acid & rat & $3.8 \%$ i.d. $\mathrm{g}^{-1}$ & 5 & 24 \\
\hline \multirow[t]{2}{*}{$6^{123 \mathrm{~m}}$ Te-telluraheptadecanoic acid } & rat & $3.4 \%$ i.d. $\mathrm{g}^{-1}$ & 5 & 24 \\
\hline & rat & $4 \cdot 1 \%$ i.d. $\mathrm{g}^{-1}$ & 60 & 24 \\
\hline 9.123mTe-tellurapentadecanoic acid & rat & $4 \cdot 4 \%$ i.d. $\mathrm{g}^{-1}$ & 5 & 24 \\
\hline 9-123m Te-telluratridecanorc acid & rat & $1.2 \%$ l.d. $\mathrm{g}^{-1}$ & 30 & 24 \\
\hline 6-123m Te-telluratridecanoic acid & rat & $1.6 \%$ i.d. $\mathrm{g}^{-1}$ & 5 & 24 \\
\hline 17.123mTe-tellura-9-heneicosenic acid & rat & $2.7 \%$ i.d. $\mathrm{g}^{-1}$ & 5 & 24 \\
\hline 17.123m Te-tellura-9-octadecenoic acid & rat & unstable in vivo & & 39 \\
\hline 17.123m-Te-tellura-9-nonadecenoic acid & rat & $020 \%$ i.d. $\mathrm{g}^{-1}$ & & 39 \\
\hline 18-methyl-17-123m Te-tellura-9-nonadecenoic acid & rat & $0.11 \%$ i.d. $g^{-1}$ & & 39 \\
\hline 3-123mTe-telluranonadecanorc acid & rat & $0 \cdot 18 \%$ i.d. $\mathrm{B}^{-1}$ & & 39 \\
\hline $17-125 \mathrm{I}$-iodo-9-telluraheptadecanoic acid & rat & $2.4 \%$ i d. $g^{-1}$ & 2 & 40 \\
\hline \multirow[t]{2}{*}{ 17-iodo-9-123mTe-telluraheptadecanoic acid } & rat & $1.4 \%$ i.d. $\mathrm{g}^{-1}$ & 2 & 40 \\
\hline & rat & $2 \cdot 2 \%$ i.d. $\mathrm{g}^{-1}$ & 30 & 40 \\
\hline $1-^{14} \mathrm{C}$-oleic acid & rat & $34 \%$ i.d. $\mathrm{g}^{-1}$ & 5 & 12 \\
\hline \multirow[t]{2}{*}{$15-\left({ }^{125}\right.$ I-4-iodophenyl)-6-tellurapentadecanoic acid } & rat & $5.9 \%$ i.d. $\mathrm{g}^{-1}$ & 5 & 41 \\
\hline & rat & $3.0 \%$ i.d. & 5 & 41 \\
\hline 18-1251-iodo-5-tellura-17-octadecenoic acid* & rat & $4.6 \%$ i.d. $\mathrm{g}^{-1}$ & 30 & 41 \\
\hline 18-1291-iodo-7-tellura-17-octadecenoic acid & rat & $3.5 \%$ i.d. $\mathrm{g}^{-1}$ & 5 & 38 \\
\hline $18-125 \mathrm{I}$-iodo-9-tellura-17-octadecenoic acid* & rat & $5.2 \%$ i.d. $\mathrm{g}^{-1}$ & 60 & 42 \\
\hline 18-125 I-1odo-11-tellura-17-octadecenoic acid* & rat & $3.6 \%$ i.d. $\mathrm{g}^{-1}$ & 60 & 42 \\
\hline 18-125I-iodo-13-tellura-17-octadecenoic acid* & rat & $1.8 \%$ i.d. $\mathrm{g}^{-1}$ & 60 & 38 \\
\hline 18-iodo-123m-Te-tellura-13-17-octadecenoic acid & rat & $20 \%$ i.d. $\mathrm{g}^{-1}$ & 60 & 38 \\
\hline
\end{tabular}

- The double bond in the 17-position is the vinyl group.

values. Interestingly, once $\mathrm{Te}$ was inserted in 18-iodo-tellura-17-octadecenoic acid in the 13-position, uptake was far less than for the 5-position ${ }^{(38.42)}$ : thus if the $T e$ is close to the carboxyl group it has a less detrimental effect on uptake values.

\section{Problems}

It is difficult to reach any general conclusions from the present knowledge on FFA uptake because of the inconsistency of the results, either from a comparison of data from different groups or even from one and the same group. Also the use of different units to express the (relative) uptake values, without giving sufficient particulars to convert the data confuses the issue. Units used are $\%$ (extraction fraction), $\%$ of injected dose per total organ, $\%$ of injected dose per gram of tissue, $\% \mathrm{~kg}$ dose per gram of tissue (which includes the body weight) (see the various tables in this review), ECAT units ${ }^{(2)}$ and $\mathrm{cpm} \mathrm{g}^{-1(11,43)}$.

Further confusion stems from the use of different experimental animals: mice, rats, rabbits, guinea pigs, dogs, calves and human beings have been studied. Particularly, the data on the small animals (mice, rats) are often reported from the fifth minute after injection, which means that no true maximum uptake values are given; the myocardial half life of FFAs in mice and rats is less than $1 \mathrm{~min}$. Longer retained activity is associated mainly with the lipid fractions in the cell.

As FFAs are very important metabolic substrates for energy production, nutrition and medication can obviously be expected to influence FFA metabolism. Nevertheless the impact on myocardial uptake has hardly been studied (Table $10^{(44-48)}$.

It has been postulated that fasted rats showed higher heart uptake of ${ }^{123} \mathrm{I}-16$-iodohexadecanoic acid than non-fasted animals ${ }^{(44)}$. Sodium pento- 
Table 10 Influence of medication and nutrition on myocardial upiake of FFAs (for abbreviations see Table I)

\begin{tabular}{|c|c|c|c|c|}
\hline FFA & Animal & Medication/nutrition & Uptake & Ref. \\
\hline${ }^{123} \mathrm{I}-16$-iodohexadecanoic acid & $\begin{array}{l}\text { rat } \\
\text { rat }\end{array}$ & $\begin{array}{l}\text { fasting as compared with non-fasting } \\
\text { sodiumpentobarbital anaesthesia in } \\
\text { fasting animal }\end{array}$ & $\begin{array}{l}43 \% \text { increase } \\
94 \% \text { decrease }\end{array}$ & $\begin{array}{l}44 \\
44\end{array}$ \\
\hline 9-123mTe-telluraheptadecanoic acid & rat & $\begin{array}{l}\text { fasting } \\
\text { high fat diet }\end{array}$ & $\begin{array}{l}5.4 \% \text { i.d. } \\
6.2 \% \text { i.d. }\end{array}$ & $\begin{array}{l}45 \\
45\end{array}$ \\
\hline $\begin{array}{l}{ }^{123} \mathrm{I}-16 \text {-iodo-9-hexadecenoic } \\
{ }^{131} \mathrm{I} \text {-16-iodo-9-hexadecenoic acid }\end{array}$ & $\begin{array}{l}\operatorname{dog} \\
\text { dog } \\
\text { dog } \\
\text { dog }\end{array}$ & $\begin{array}{l}\text { heparin }+ \text { intralipıd } \\
\text { heparin alone } \\
\text { glucose }+ \text { insulin }+\mathbf{K} \\
\text { betablockade with pindolol } \\
\text { [control }\end{array}$ & $\begin{array}{l}\text { increase } \\
\text { no effect } \\
\text { increase } \\
1 \cdot 2 \% \text { i.d. }(5 \mathrm{~min}) \\
2.9 \% \text { i.d. }\end{array}$ & $\begin{array}{l}46 \\
46 \\
46 \\
47 \\
47]\end{array}$ \\
\hline${ }^{131}$ I-17-iodoheptadecanoic acid & $\operatorname{dog}$ & $\begin{array}{l}\text { beta blockade with pindolol } \\
\text { beta blockade with metoprolol } \\
\text { beta blockade with timolol } \\
\text { beta blockade with propranolol } \\
\text { [control }\end{array}$ & $\begin{array}{l}2 \cdot 5 \% \text { i.d. } \\
2 \cdot 4 \% \text { i.d. } \\
2 \cdot 7 \% \text { i.d. } \\
3.8 \% \text { i.d. } \\
4 \cdot 2 \% \text { i.d. }(5 \mathrm{~min})\end{array}$ & $\begin{array}{l}48 \\
48 \\
48 \\
48 \\
48]\end{array}$ \\
\hline
\end{tabular}

barbital anaesthesia decreased tracer uptake especially in non-fasted animals. The fasting effect was not found with ${ }^{123 m} \mathrm{Te}$-9-tellura-heptadecanoic $\operatorname{acid}^{(45)}$.

Treatment with heparin plus intralipid or with glucose plus insulin plus potassium increased myocardial accumulation of ${ }^{123} \mathrm{I}-16$-iodo9-hexadecenoic acid in the heart of the dog. Heparin along had no effect ${ }^{(46)}$.

The beta blocker pindolol decreased uptake of this tracer ${ }^{(47)}$. Treatment with beta blockers also reduced the uptake of 17-iodoheptadecanoic acid ${ }^{(48)}$.

Thus data on the influence of nutrition and medication are notably scanty and as yet allow for no conclusions to be drawn.

\section{Conclusions}

Although a great many problems remain to be solved, some general conclusions can be drawn:

Myocardial uptake is highest for the long-chain FFAs with a carbon chain of 16 or $18 \mathrm{C}$-atoms.

Differences in uptake as a consequence of the number of $\mathrm{C}$-atoms being odd or even (odd numbered FFAs are taken up to a lesser extent) require further study.

Branching of the chain by introduction of a methylgroup or the bigger halogens reduces myocardial uptake. The small fluorine atom only has an effect on uptake in the 2-position (beside the carboxyl group) because of its influence on the acid strength.
Substitution at the end of the C-chain reduces uptake only when it results in higher polarity of the molecule.

A double bond in the carbon chain [either in the middle or at the end (omega-vinyl-)] does not appreciably influence uptake in the heart, whereas a triple bond causes appreciable reduction.

The replacement of one of the C-atoms of the chain by a tellurium atom reduces uptake, once the $\mathrm{Te}$ is too close to either end of the molecule; a Te in the middle leaves uptake essentially unaffected.

Myocardial uptake of FFAs has been considered to proceed by passive diffusion. However, this would not account for all observed selectivities, the structure-activity relationships described above. It seems more likely that two mechanisms operate: (a) passive diffusion, favouring the more lipofilic, longchain FFA, which is reduced once the molecule is made more polar by substitution and (b) a carrier mediated mechanism, which favours FFAs with an appropriate length of 16 or $18 \mathrm{C}$-atoms.

An impressive number of various FFAs have now been synthesized and used in various biological experiments. In our opinion there is at present no need for more variations on this theme, but the available compounds must be used to do the appropriate biological research. In this respect the search for better uptake characteristics seems of less importance than understanding the dynamic behaviour of the favoured compound; higher uptake can hardly be expected, considering the abovementioned structure-activity relationships, whereas 
the importance of (very) long retention times is a question of interpretation. Unless a compound can be found which depicts reversibly ischaemic areas in the heart at rest (without exercise), FFAs do not present an improvement with regard to ${ }^{201} \mathrm{Tl}$ thallium for the localization of ischaemia. But possibly a fair understanding of dynamic FFA behaviour under normal and pathological conditions may turn radiolabelled FFAs into a useful diagnostic tool.

In further biological research, more unity in the execution of the experiments and the presentation of the data would be advantageous. We have argued ${ }^{(48)}$ that the uptake in \% of injected dose per total heart is more relevant than, e.g. the more used \% of injected dose per gram of organ, but whatever ones opinion on this, all relevant data should be given, to enable the results in one favoured set of units to be converted to another.

\section{References}

(1) Lerch RA, Bergmann SR, Ambos HD, Welch MJ, Ter-Pogossian MM, Sobel BE. Effect of flowindependent reduction of metabolism on regional myocardial clearance of C-11-palmitate. Circulation 1982; 65: 731-8.

(2) Schelbert HR. Stoffwechsel des Herzens: Neue Untersuchungsmoeglichkeiten durch Positronen-ComputerTomographie. Der Nuklearmediziner 1983; 6: 3-23.

(3) Poe ND, Robinson GD Jr, MacDonald NS. Myocardial extraction of labeled long-chain fatty acid analogs. Proc Soc Exp Biol Med 1975; 148: 215-8.

(4) Schelbert HR, Henze E, Schoen HR et al. C-11 palmitate for the noninvasive evaluation of regional myocardial fatty acid metabolism with positron computed tomography. III. In vivo demonstration of the effects of substrate availability on myoc metabolism. Am Heart J 1983; 105: 492-504.

(5) Weiss ES, Hoffman EJ, Phelps ME et al. External detection and visualization of myocardial ischemia with C-11-substrates in vitro and in vivo. Circ Res 1976; 39: 24-32.

(6) Machulla HJ, Stoecklin G, Kupfernagel C et al. Comparative evaluation of fatty acids labeled with Cl-11, C-34m, Br-77 and I-123 for metabolic studies of the myocardium: concise communication. J Nucl Med 1978; 19: 298-302.

(7) Elmaleh DR, Livni E, Shlomo L, Varnum D, Strauss $\mathrm{HW}$, Brownell GL. Comparison of $\mathrm{C}-11$ and $\mathrm{C}-14$ labeled fatty acids and their beta-methyl analógs. Int $\mathrm{J}$ Nucl Med Biol 1983;10: 181-7.

(8) Ji Q, Wang $Y$, Zhang $J$ et al. In vivo distribution and organ imaging of C-11-benzoic acid and C-11propionic acid in animals. Nucl Tech $1983 ; 6$ : 65-6.

(9) Selwyn AP, MacArthur C, Allan R, Pike V, Jones T. Myocardial ischemia; metabolic studies using positron tomography. Eighth Eur Congr Cardiol Paris, 1980: 194 (Abstr).

(10) Evans JR, Gunton RW et al. Use of radioiodinated fatty acid for photoscans of the heart. Cire Res 1965; 16: $1-10$.

(11) Bonte FJ, Graham KD, Moore JG. Experimental myocardial imaging with I-131-labeled oleic acid. Radiology 1973; 108: 195-6.

(12) Beierwaltes WH, Ice RD, Shaw MJ, Ryo UY. Myocardial uptake of labeled oleic and linoleic acids. J Nucl Med 1975; 16: 842-5.

(13) Knust EJ, Kupfernagel C, Stoecklin G. Long-chain F-18 fatty acids for the study of regional metabolism in heart and liver; odd-even effects of metabolism in mice. J Nucl Med 1979; 20: 1170-5.

(14) Elmaleh DR, Knapp FF $\mathrm{Jr}$, Yasuda $\mathrm{T}$ et al. Myocardial imaging with 9-[Te-123m]telluraheptadecanoic acid. J Nucl Med 1981; 22: 994-9.

(15) Riche F, Mathieu JP, Busquet G et al. Etude biologique d'acides gras en C-16 marques par un atome radioactif. J Biophys Med Nucl 1983; 7: 87-95.

(16) Angelberger $P$, Wagner-Loeffler $M$, Dudczak $R$, Hruby R. I-123(131)-labeled aliphatic and aromatic fatty acids: optimized preparation and biodistribution. Radioakt Isot Klin Forsch 1982; 15: 249-64.

(17) Riche F, Mathieu JP, Comet $M$ et al. Influence de la longueur de la chaine et du nombre pair ou impair d'atoms de carbone sur le comportement biologique des acides gras iodes. J Biophys Med Nucl 1983; 7: 97-106.

(18) Reske SN, Auner G, Winkler C. Kinetics of 17-(I-123) iodoheptadecanorc acid in myocardium of rats. J Radioanal Chem 1983; 79: 355-61.

(19) Westera G, Van der Wall EE, Visser FC, Den Hollander W, Heidendal GAK, Roos JP. The uptake of iodinated free fatty acids in the (ischemic) dog heart. Indications for a dual uptake mechanism. Int $\mathbf{J}$ Nucl Med Biol 1983; 10: 231-6.

(20) Otto CA, Brown LE, Wieland DM, Beierwaltes WH. Radioiodinated fatty acids for myocardial imaging: Effects of chain length. J. Nucl Med 1981; 22: 613-8.

(21) Okada RD, Elmaleh D, Werre GS, Strauss HW. Myocardial kinetics of I-123-labelled-16-hexadecanoic acid. Eur J Nucl Med 1983; 8: 211-7.

(22) Otto CA, Brown LE, Wieland DM, Beierwaltes WH. Synthesis of 125-I-labeled 14-iodo- 9-tetradecynoic acid. J Labeled Comp Radiopharm XVIII: 1981; 1347-55.

(23) Sun QX, Zhang J, Ji QM et al. Pharmacology of radioiodinated hexadecenoic acid. A myocardial imaging agent. Nucl Med 1984; 23: 73-4.

(24) Knapp FF Jr, Ambrose KR, Callahan AP, Ferren LA, Gribsby RA, Irgolic KJ. Effects of chain length and tellurium position on the myocardial uptake of Te-123m fatty acids. J Nucl Med 1981; 22: 988-93.

(25) Machulla HJ, Dutschka K, Marsmann M, Van Beuningen D. Radiopharmaceuticals III. Synthesis and myocardial uptake of 5-p-123-1-phenyl valeric acid. Radiochem Radioanal Lett 1981; 46: 317-22.

(26) Martin DW, Mayes PA, Rodwell VW (eds). Harper's biochemistry. Lange Medical Publications, 18 th ed. 1981.

(27) Machulla HJ, Marsmann M, . Dutschka K, Van Beuningen D. Radiopharmaceuticals II. Radiobromination of phenylpentadecanoic acid and biodistribution in mice. Radiochem Radioanal Lett 1980; 42: 243-50. 
(28) Angelberger $P$, Wagner-Loffler $M$, Dudczak $R$ et al. 123-I and 131-I labeled p-Iodophenyl pentadecanoic acid: simplified preparation, biodistribution in mice, rabbits and patients. In: $\mathrm{Cox} \mathrm{PH}$, ed. Progress in radiopharmacology, vol. 2. Elsevier/North Holland Biomedical Press, 1981: 61-74.

(29) Ercan M, Senekowitsch R, Bauer R, Reidel G, Kriegel $\mathrm{H}$, Pabst $\mathrm{HW}$. In vivo and in vitro studies with omega[p-I-123-phenyl]-pentadecanoic acid in rats. Int J Appl Radiat Isot 1983; 34: 1519-24.

(30) Reske SN. Jod-123-Phenyl-Pentadecansaeure: Ein neuer Tracer zur Untersuchung des myokardialen Metabolismus freier Fettsacuren. Der Nuklearmediziner 1983; 6: 25-46.

(31) Goodman MM, Kirsch G, Knapp FF Jr. Synthesis and evaluation of radioiodinated terminal p-iodophenyl-substituted alpha- and beta-methyl branched fatty acids. J Med Chem 1984; 27 : 390-7.

(32) Reske SN, Schoen S, Knust EJ et al. Relation of myocardial blood flow and initial cardiac uptake of 15-(p-I-123-phenyl)-pentadecanoic acid in the canine heart. Nucl Med 1984; 23: 83-5.

(33) Coenen HH, Harmand MF, Kloster G, Stoecklin G. 15-(p-[Br-75]bromophenyl)-pentadecanoic acid: Pharmacokinetics and potential as heart agent. J Nucl Med 1981; 22: 891-6.

(34) Fritzberg AR, Eshima D. Iodophenyl-sulfonamide fatty acid analogs as potential myocardial imaging agents. Int J Appl Radiat Isot 1982; 33: 451-53.

(35) Knapp FF Jr, Goodman MM, Kabalka GW, Sastry KAR. Synthesis and evaluation of radioiodinated (E)-18-iodo-17-octadecenoic acid as a model iodoalkenyl fatty acid for myocardial imaging. J Med Chem 1984; 27: 94-7.

(36) Livni E, Elmaleh DR, Levy S, Brownell GL, Strauss WH. Beta-methyl[1-C-11]heptadecanoic acid: A new myocardial metabolic tracer for positron emission tomography. J Nucl Med 1982; 23: 169-75.

(37) Otto CA, Brown LE, Scott AM. Radioiodinated branched-chain fatty acids: Substrates for beta oxidation? Concise communication. J Nucl Med 1984; 25: $75-80$.

(38) Knapp FF Jr, Goodman MM, Callahan AP, Ferren LA, Kabalka GW, Sastry KAR. New myocardia] imaging agents: stabilization of radioiodine as a terminal vinyl iodide moiety on tellurium fatty acids. I Med Chem 1983; 26: 1293-300.

(39) Basmadjian GP, Mills SL, Ice RD. Synthesis, biological distribution and radiation dosimetry of tellurium-123m analogs of hexadecenoic acid. Nucl Med Commun 1982; 3: 150-4.

(40) Goodman MM, Knapp FF, Callahan AP, Ferren LA. Synthesis and biological evaluation of 17-(131-I)iodo9-tellura- heptadecanoic acid, a potential myocardial imaging agent. J Med Chem 1982; 25: 6I3-8.

(41) Goodman MM, Knapp FF Jr, Callahan AP, Ferren LA. A new, well-retained myocardial imaging agent: radioiodinated 15-(p-Iodophenyl)-6-tellura-pentadecanoic acid. J Nucl Med 1982; 23: 904-8.

(42) Knapp FF Jr, Srivastava PC, Callahan AP, Cunningham EB, Kabalka GW, Sastry KAR. Effect of tellurium position on the myocardial uptake of radioiodinated 18-iodotellura- 17-octadecenoic acid analogues. J Med Chem 1984; 27: 57-63.

(43) Chien. KR, Han A, White J, Kulkarni P. In vivo esterification of a synthetic I-125 labeled fatty acid into cardiac glycerolipids. Am J Physiol 1983; 245: 693-7.

(44) Brown LE, Mangner TJ, Marsh DD, Otto CA, Wieland DM, Beierwaltes WH. Effects of nutritive state and anesthesia on heart uptake of fatty acid. J Nucl Med 1981; 21: P 73.

(45) Elmaleh DR, Knapp FF, Yasuda T, Kopiwoda S, McKusick KA, Strauss HW. 123m-Te-9-telluraheptadecanoic acid as myocardial imaging agent. J Nucl Med 1980; 21: P58.

(46) Comet M, Pilichowski P, Wolf JE et al. Myocardial scintigraphy with i.v. injections of 16-[I-123]iodo9-hexadecenoic acid. Effect of plasma concentrations of fatty acids and glucose. J Biophys Med Nucl 1983; 7: 151-7.

(47) Van der Wall EE, Westera G, Den Hollander W, Visser FC, Roos JP, Heidendal GAK. The effect of pindolol on myocardial uptake of free fatty acids in the dog. Curr Ther Res 1983; 33: 591-600.

(48) Westera G, Van der Wall EE, Eenige van MJ et al. Metabolic consequences of beta-adrenergic receptor blockade for the acutely ischemic dog myocardium. Nuklearmedizin 1984; 23: 35-40. 